\title{
[Letter]
}

\section{Combustion of Toluene over Titanium(IV) Oxide Catalyst}

\author{
${\text { Byonggu } \mathrm{AN}^{* 1)} \text {, Sachiko KAIDA }}^{\dagger 1)}$, Tohru MIYAKE ${ }^{\dagger 1)}$, Tohru TANI ${ }^{\dagger 1 *}$, Itsushi KASHIMOTO ${ }^{\dagger 2)}$, and Hiroshi \\ KOMINAMI $^{\dagger 3} *$ \\ ${ }^{\dagger 1)}$ Department of Surgery, School of Medicine, Shiga University of Medical Science, \\ Seta Tsukinowa-cho, Ohtsu, Shiga 520-2192, JAPAN \\ ${ }^{\dagger 2}$ Kusatsu Electric Co., Ltd., Higashikusatsu, Kusatsu, Shiga 525-8501, JAPAN \\ ${ }^{\$ 3}$ Department of Applied Chemistry, Faculty of Science and Engineering, Kinki University, \\ Kowakae, Higashiosaka, Osaka 577-8502, JAPAN
}

(Received June 21, 2007)

\begin{abstract}
Combustion catalysts free from precious metals, such as platinum, for removal of volatile organic compounds were investigated. Common metal oxides (titanium(IV) oxide $\left(\mathrm{TiO}_{2}\right)$, alumina and silica) were selected as candidates for a catalyst for combustion of toluene at low concentrations. Complete conversion of toluene was not achieved even at $500^{\circ} \mathrm{C}$ without catalysts, although the ignition point of toluene is $480^{\circ} \mathrm{C} . \quad \mathrm{TiO}_{2}$ exhibited the highest activity for combustion of toluene among representative metal oxides. Toluene was almost quantitatively converted to carbon dioxide ( $>99 \%$ yield) over $\mathrm{TiO}_{2}$ under the condition of appropriate contact time at $500^{\circ} \mathrm{C}$.
\end{abstract}

\section{Keywords}

Combustion catalyst, Titanium oxide catalyst, Volatile organic compounds, Toluene

\section{Introduction}

Volatile organic compounds (VOC) such as toluene have serious impacts on the environment and human health. It has been reported that toluene and formaldehyde are related to sick-house syndrome ${ }^{1)}$. Emission of VOC from factories into the atmosphere is now strictly regulated in Japan. When industrial wastes including medical wastes are degraded, large amounts of VOC are formed. Therefore, there is a need for effective and safe degradation methods for VOC as well as for medical wastes ${ }^{2), 3)}$. Catalytic combustion method using supported platinum metal $(\mathrm{Pt})$ is at present the most promising method for removal of VOC in low concentrations $^{4)-6)}$. However, a Pt catalyst is generally deactivated within several years due to sintering of $\mathrm{Pt}$ particles and poisoning by sulfur contained in VOC and that from the environment. Replacement with a fresh catalyst increases the cost for maintenance. Rare elements such as the platinum group are produced in limited areas of the world and the supplies of these metals sometimes become unstable. Therefore, it is important to develop a new material made of a common and cheap element that has almost the same level of function (or performance) as that of a material made of a rare element. Research on transparent electrodes without using indium ${ }^{7)}$ is typical case of "element strategy." Also, in the field of catalytic materials, especially supported precious metal catalysts such as Pt, rhodium and palladium, development of combustion catalysts free from precious metals is important. Supported gold catalysts $^{8)}$, manganese oxide-based catalysts, perovskite-type catalysts ${ }^{9)}$ and hexaaluminatebased catalysts ${ }^{10)}$ are combustion catalysts free from the precious metals, and some of these catalysts have been used as practical catalysts. However, it is necessary to investigate catalyst materials made of more common element(s) and having a simpler structure.

We chose titanium(IV) oxide (titania, $\mathrm{TiO}_{2}$ ), active alumina and silica as the candidates for combustion catalyst of VOC because of several reasons as follows:1) They have large Klarke number. 2) They have been already used as catalyst materials in various fields. 3) They exhibit high stability toward chlorine or hydrogen chloride, which is important for combustion of chlorinated VOC. 4) They exhibit high thermal stability and possess large surface area. 5) Many samples

“酸化チタン(IV)触媒によるトルエンの燃焼”

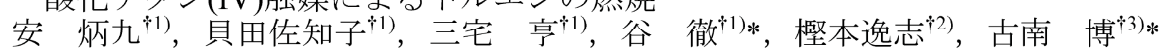

†1 滋賀医科大学外科学講座, 520-2192 大津市濑田月輪町, ‘2)草津電機株式会社, 525-8501 草津市東草津

$2-3-38$, 湫近畿大学理工学部応用化学科, 577-8502 東大阪市小若江 3-4-1

*Corresponding authors, E-mail: tan@belle.shiga-med.ac.jp, hiro@apch.kindai.ac.jp 
having various physical properties are provided. 6) Moldings of these compounds are easily obtained. In this study, we selected toluene as a model compound of VOC and examined the combustion of toluene at a low concentration over $\mathrm{TiO}_{2}$, alumina and silica.

\section{Experimental}

Degradation of toluene was carried out using a fix-bed, flow-type reactor. In a stainless reactor (SUS306, 29.4 $\mathrm{mm}$ in diameter, $355 \mathrm{~mm}$ in length, $240 \mathrm{~cm}^{3}$ in volume), weighed sample was charged (air space in the reactor: $154 \mathrm{~cm}^{3}$ ). Toluene (Wako Pure Chem. Ind., Ltd.) gas (mainly $2100 \mathrm{ppm}$ ) diluted with air was introduced to the reactor at $250-500^{\circ} \mathrm{C}$ with several flow rates $(0.25-1.00$ $\left.\mathrm{dm}^{3} \cdot \mathrm{min}^{-1}\right)$. Concentrations of carbon dioxide $\left(\mathrm{CO}_{2}\right)$ and carbon monoxide (CO) in the outlet gas were continuously analyzed with a gas analyzer (Horiba, Ltd., PG-250). The concentration of toluene was determined with a gas chromatograph (Shimadzu Corp., GC-14A, PEG 1500 15\% Chromosorb W, $\phi 3 \mathrm{~mm} \times 2 \mathrm{~m}$ ).

Apparent carbon yields $\left(Y_{\mathrm{C}}\right)$ were calculated from the following Eq. 1:

$$
Y_{\mathrm{C}}=\frac{C \mathrm{CO}+\mathrm{CCO}_{2}}{7 \times C_{\mathrm{T}} \times X_{\mathrm{T}} / 100} \times 100
$$

where $C \mathrm{CO}$ and $\mathrm{CCO}_{2}$ are concentrations of $\mathrm{CO}$ and $\mathrm{CO}_{2}$ in outlet gas, $C_{\mathrm{T}}$ is concentration of toluene in inlet gas and $X_{\mathrm{T}}$ is conversion of toluene.

\section{Results and discussion}

Results of combustion of toluene over $\mathrm{TiO}_{2}$, active alumina and silica with flow rate of $0.25 \mathrm{dm}^{3} \cdot \mathrm{min}^{-1}$ at $500^{\circ} \mathrm{C}$ are summarized in Table 1. Almost complete conversion of toluene $(>99 \%)$ and $65 \%$ of yield of $\mathrm{CO}_{2}$ were obtained over $\mathrm{TiO}_{2}$. A very small yield of $\mathrm{CO}_{2}$ was obtained over active alumina, although the conversion of toluene was almost the same as that over $\mathrm{TiO}_{2}$. Moreover, $Y_{\mathrm{C}}$ for active alumina was less than half of that for $\mathrm{TiO}_{2}$, suggesting that acid sites of active alumina caused carbonization of toluene and deposition of carbon (coking). Less conversion of toluene and much larger yield of $\mathrm{CO}$ were obtained over silica. Result without a catalyst (blank test) is also summarized in Table 1. Low conversion of toluene was observed in the blank test, although the ignition point of toluene is $480^{\circ} \mathrm{C}$. These results indicate that complete combustion of toluene is not achieved even in the presence of transition metals (or their oxides) of the stainless reactor at $500^{\circ} \mathrm{C}$ under the present conditions if the concentration of toluene is low.
Table 1 Combustion of Toluene over Various Metal Oxides at $500^{\circ} \mathrm{C}^{\mathrm{a})}$

\begin{tabular}{cccccc}
\hline $\begin{array}{c}\text { Metal } \\
\text { oxide }\end{array}$ & $\begin{array}{c}\mathrm{CT}^{\mathrm{b})} \\
{[\mathrm{ppm}]}\end{array}$ & $\begin{array}{c}X_{\mathrm{T}}{ }^{\mathrm{c})} \\
{[\%]}\end{array}$ & $\begin{array}{c}Y_{\mathrm{CO}_{2}{ }^{\mathrm{d})}}^{[\%]} \\
{[\%}\end{array}$ & $\begin{array}{c}Y_{\mathrm{CO}}{ }^{\mathrm{e})} \\
{[\%]}\end{array}$ & $\begin{array}{c}Y_{\mathrm{C}}{ }^{\mathrm{f})} \\
{[\%]}\end{array}$ \\
\hline $\mathrm{TiO}_{2}{ }^{\mathrm{g})}$ & 2038 & $>99$ & 65 & 5.3 & 70 \\
$\mathrm{TiO}_{2}{ }^{\mathrm{g})}$ & 1390 & $>99$ & $>99$ & 0.7 & $>99$ \\
$\mathrm{Al}_{2} \mathrm{O}_{3}{ }^{\mathrm{h})}$ & 2000 & $>99$ & 27 & 0.1 & 27 \\
$\left.\mathrm{SiO}_{2}{ }^{\mathrm{i}}\right)$ & 1203 & 87 & 32 & 16 & 55 \\
$\left.\mathrm{j}^{\mathrm{j}}\right)$ & 1696 & 55 & 14 & 5.5 & 36
\end{tabular}

a) Flow rate: $0.25 \mathrm{dm}^{3} \cdot \mathrm{min}^{-1}$. b) Initial concentration.

c) Conversion of toluene.

d) $\mathrm{CO}_{2}$ yield. e) $\mathrm{CO}$ yield.

f) Apparent carbon yield calculated from the concentrations of $\mathrm{CO}_{2}$ and $\mathrm{CO}$ and initial concentration and conversion of toluene.

g) Anatase-type, Sakai Chemical Industry Co., Ltd., SSP-G, $167 \mathrm{~g}$.

h) Activated alumina, Nacalai Tesque, Inc., $160 \mathrm{~g}$.

i) Silica, Nacalai Tesque, Inc., $129 \mathrm{~g}$.

j) Blank test (No metal oxide).

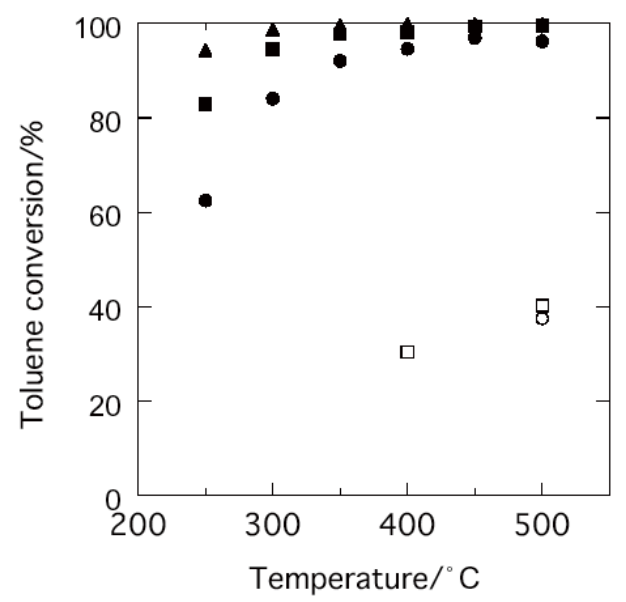

Closed circles: $1.00 \mathrm{dm}^{3} \cdot \mathrm{min}^{-1}$, closed squares: 0.50 $\mathrm{dm}^{3} \cdot \mathrm{min}^{-1}$, closed triangles: $0.25 \mathrm{dm}^{3} \cdot \mathrm{min}^{-1}$. Open circles and squares: blank tests (reactions without $\mathrm{TiO}_{2}$ ) with flow rates of 1.00 and $0.50 \mathrm{dm}^{3} \cdot \mathrm{min}^{-1}$, respectively.

Fig. 1 Effects of Reaction Temperature on Conversion of 2100 ppm Toluene with Various Flow Rates

Low $Y_{\mathrm{C}}$ in the blank test indicates that large amounts of partially-oxidized product(s) of toluene and solid-type carbon were formed without a catalyst under the present conditions. These comparisons clearly show that $\mathrm{TiO}_{2}$ exhibited the best result for combustion of toluene among common and simple metal oxides, although there has been little investigation of (thermo)catalysis of $\mathrm{TiO}_{2}$ 

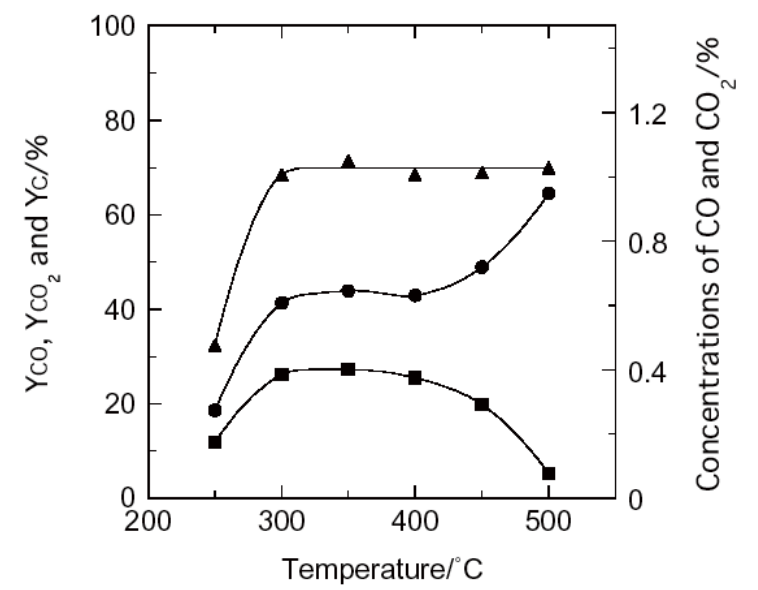

Fig. 2 Effects of Reaction Temperature on Yield of $\mathrm{CO}_{2} \quad\left(Y_{\mathrm{CO}_{2}}\right.$, circles $)$ and $\mathrm{CO}\left(Y_{\mathrm{CO}}\right.$, squares) and Apparent Carbon Yield $\left(Y_{\mathrm{C}}\right.$, triangles) in Combustion of $2100 \mathrm{ppm}$ Toluene at a Rate of $0.25 \mathrm{dm}^{3} \cdot \mathrm{min}^{-1}$

itself at high temperatures. It has recently been reported that polymers such as polycarbonate were degraded by thermocatalysis of $\mathrm{TiO}_{2}$ at temperatures around $500^{\circ} \mathrm{C}^{11)-13)}$.

The effects of reaction temperature on conversion of toluene with various flow rates $(1.00,0.50$ and 0.25 $\mathrm{dm}^{3} \cdot \mathrm{min}^{-1}$ ) over $\mathrm{TiO}_{2}$ are shown in Fig. 1. For comparison, results of blank tests (reactions without $\mathrm{TiO}_{2}$ ) are also shown. Conversions of toluene without $\mathrm{TiO}_{2}$ at $500^{\circ} \mathrm{C}$ were $38 \%$ and $40 \%$ with flow rates of 1.00 and $0.50 \mathrm{dm}^{3} \cdot \mathrm{min}^{-1}$, respectively. In the presence of $\mathrm{TiO}_{2}$, more than $60 \%$ of toluene was converted at $250^{\circ} \mathrm{C}$ at all flow rates. Conversion of toluene was increased by elevating the reaction temperature, and the conversion exceeded $90 \%$ at $400^{\circ} \mathrm{C}, 300^{\circ} \mathrm{C}$ and $250^{\circ} \mathrm{C}$ when the flow rates were $1.00,0.50$ and $0.25 \mathrm{dm}^{3} \cdot \mathrm{min}^{-1}$, respectively. Since conversion of more than $96 \%$ was achieved at $500^{\circ} \mathrm{C}$ under all reaction conditions, it is concluded that $\mathrm{TiO}_{2}$ has some effect on reaction of toluene.

Effect of reaction temperature on yields of products and $Y \mathrm{c}$ with a flow rate of $0.25 \mathrm{dm}^{3} \cdot \mathrm{min}^{-1}$ is shown in Fig. 2. Yields of gaseous products, $\mathrm{CO}_{2}$ and $\mathrm{CO}$, were low (19\% and $12 \%$, respectively) at $250{ }^{\circ} \mathrm{C}$, though the conversion of toluene was relatively high $(94 \%)$. Very low $Y_{\mathrm{C}}(32 \%)$ at $250^{\circ} \mathrm{C}$ suggests that a non-volatile product(s) was formed at that temperature. An intermediate compound(s) such as benzoic acid or maleic anhydride having a high boiling point was probably formed by partial oxidation of toluene and deposited on the surface of $\mathrm{TiO}_{2}$ and around the exit of the reactor used in this study. However, since analysis of

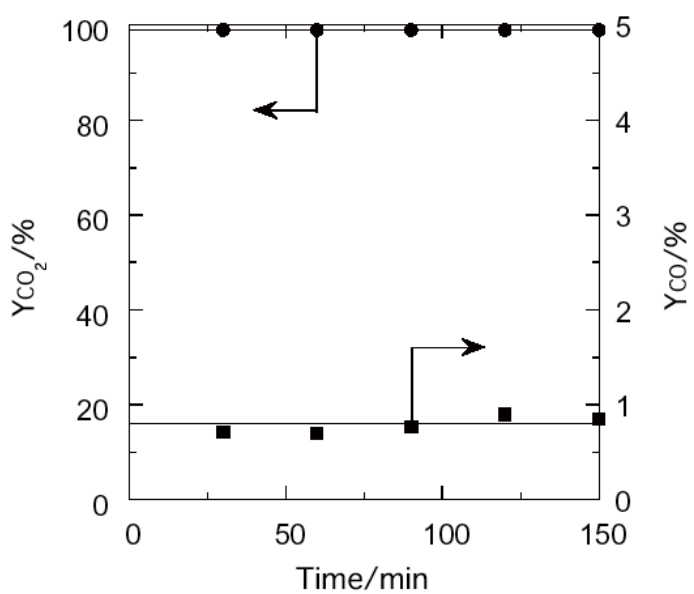

Fig. 3 Time-dependency of Yields of $\mathrm{CO}_{2}$ (circles) and CO (squares) in Combustion of 1390 ppm Toluene under the Condition of a Flow Rate of $250 \mathrm{dm}^{3} \cdot \mathrm{min}^{-1}$ at $500^{\circ} \mathrm{C}$

compounds having high boiling temperatures is generally difficult, identification and quantitative analysis of the intermediate(s) is now in progress.

When the reaction temperature was elevated to $300^{\circ} \mathrm{C}$, yields of $\mathrm{CO}_{2}$ and $\mathrm{CO}$ were increased and $Y_{\mathrm{C}}$ was improved $(68 \%)$, indicating that successive oxidation of the intermediate to $\mathrm{CO}$ and $\mathrm{CO}_{2}$ occurred at this temperature. Product distribution was almost the same in the temperature range of 300 to $400^{\circ} \mathrm{C}$. The yield of $\mathrm{CO}$ was decreased and the yield of $\mathrm{CO}_{2}$ was increased at $450^{\circ} \mathrm{C}$. These results indicate that reaction rate for oxidation of $\mathrm{CO}$ to $\mathrm{CO}_{2}$ was increased at this temperature. At $500^{\circ} \mathrm{C}$, oxidation of $\mathrm{CO}$ to $\mathrm{CO}_{2}$ was further accelerated and most of the gaseous product was $\mathrm{CO}_{2}$, i.e., selectivity of $\mathrm{CO}_{2}$ in gaseous products reached $92 \%$. $Y_{\mathrm{C}}$ increased up to $300^{\circ} \mathrm{C}$. However, $Y_{\mathrm{C}}$ remained almost the same $(70 \%)$ up to $500^{\circ} \mathrm{C}$. Since the intermediate(s) with a high boiling point was probably degraded at around $400-500^{\circ} \mathrm{C}$, the low $Y_{\mathrm{C}}$ at these temperatures is attributable to formation of a solid-type carbon such as soot. It has been reported that temperature for self-combustion of solid-type carbon in the presence of oxygen was higher than $650^{\circ} \mathrm{C}$ and that the combustion temperature over a catalyst having an excellent oxidation activity is around $570^{\circ} \mathrm{C}^{14)}$. Therefore, since solid-type carbon was partially formed from toluene under the present reaction conditions and was emitted out of the system without being oxidized, $Y_{\mathrm{C}}$ was decreased.

The rate of $\mathrm{CO}_{2}$ formation over $\mathrm{TiO}_{2}$ at $500^{\circ} \mathrm{C}$ was calculated to be $0.62 \mu \mathrm{mol} \cdot \mathrm{min}^{-1} \cdot \mathrm{g}-\mathrm{TiO}_{2}{ }^{-1}$. The maximum concentration of toluene for $100 \%$ yield of 
$\mathrm{CO}_{2}$ was estimated to be $c a .1300 \mathrm{ppm}$ based on the assumption that the rate of $\mathrm{CO}_{2}$ formation was independent of the initial concentration of toluene. The results are also shown in Table 1. As expected, 1390 ppm of toluene almost quantitatively converted to $\mathrm{CO}_{2}$ over $\mathrm{TiO}_{2}$ under the same flow rate. Time-dependency of combustion of toluene under the same condition is show in Fig. 3, indicating that mineralization of toluene to $\mathrm{CO}_{2}$ over $\mathrm{TiO}_{2}$ continuously occurred within the reaction period $(2.5 \mathrm{~h})$ examined in this study.

In conclusion, in the course of research on "element strategy" for a combustion catalyst, we focused on $\mathrm{TiO}_{2}$ alumina and silica, which are abundant as a resource and have simple composition, and examined combustion of toluene over these metal oxides. Among them, $\mathrm{TiO}_{2}$ exhibited the highest activity for combustion of toluene. Toluene was almost quantitatively mineralized to $\mathrm{CO}_{2}$ $\left(>99 \%\right.$ yield of $\left.\mathrm{CO}_{2}\right)$ under the condition of appropriate contact time at $500^{\circ} \mathrm{C}$.

This work was partly supported by New Industry Creative-Type Technology R\&D Promotion Programs from The Kansai Bureau of Economy, Trade and Industry. We thank Sakai Chemical Industry Co., Ltd. for the supply of $\mathrm{TiO}_{2}$ sample (SSP-G) and we thank Dr. Yamamoto (SUMS) for his permission for us to use his $\mathrm{GC}$ for analysis of the concentration of toluene. $\mathrm{Mr}$. Shigehara (SUMS) and Dr. Hashimoto (Kinki U.) are acknowledged for their help in evaluation and discussion of catalytic activities in combustion of toluene.

\section{References}

1) Weislander, G., Norbäck, D., Björnsson, E., Janson, C., Boman, G., Int. Arch. Occup. Environ. Health, 69, 115 (1997).

2) "USEPA Inventory of US Greenhause Gas Emissions and Sinks: 1990-1997," US EPA, Washington, DC (1999).

3) Mukhopadhyay, N., Moretti, E. C., "Reducing and Controlling Volatile Organic Compounds, Centre for Waste Reduction Technologies," AIChE, New York (1993).

4) Spivey, J. J., Ind. Eng. Chem. Res., 26, 2165 (1987).

5) Vigneron, S., Deprelle, P., Hermia, J., Catal. Today, 27, 229 (1996).

6) Sharma, R. K., Zhou, B., Toung, S., Chuang, K., Ind. Eng. Chem. Res., 34, 4310 (1995).

7) Sushko, P. V., Shluger, A. L., Hayashi, K., Hirano, M., Hosono, H., Physical Rev. B, 73, 045120 (2006).

8) Haruta, M., Yamada, N., Kobayashi, T., Iijima, S., J. Catal., 115, 22 (1989).
9) Misono, M., Mizuno, N., Ceram. Trans., 73, 67 (1997).

10) Machida, M., Sato, A., Kijima, T., Inoue, H., Eguchi, K., Arai, H., Catal. Today, 26, 239 (1995).

11) Mizuguchi, J., J. Electrochem. Soc., 148, J55 (2001).

12) Mizuguchi, J., Shinbara, T., J. Appl. Phys., 96, 3514 (2004).

13) Shinbara, T., Makino, T., Matsumoto, K., Mizuguchi, J., J. Appl. Phys., 98, 044909 (2005).

14) Takami, A., Harada, K., Tsushio, Y., J. Jpn. Petrol. Inst., 50, (2), 102 (2007). 